\title{
ANALISIS PENYELESAIAN SENGKETA LINGKUNGAN NON-LITIGASI ANTARA PERUSAHAAN PERKEBUNAN KELAPA SAWIT DENGAN WARGA DESA SIDOMULYO, KABUPATEN OGAN KOMERING ILIR (Analysis of Non-Litigation Environmental Dispute Settlement between Oil Palm Plantation Company and Sidomulyo Villagers, Ogan Komering Ilir District)
}

\author{
Muhammad Syaifuddin ${ }^{1 *}$, Adrian Nugraha1 dan Ade Uswatun Hasanah ${ }^{2}$ \\ ${ }^{1}$ Fakultas Hukum Universitas Sriwijaya, Kampus Fakultas Hukum Bukit Besar, J1. Srijaya Negara, \\ Bukit Besar, Palembang, Sumatera Selatan, 30139. \\ ${ }^{2}$ Pusat Penelitian Lingkungan Hidup Universitas Sriwijaya, Jalan Padang Selasa No. 522 Mess \\ Unsri Griya Asri, Bukit Besar Palembang 30139.
}

*Penulis korespondensi. Tel: 08153551260. Email: msyaifuddinunsri73@gmail.com.

\begin{abstract}
Abstrak
Penelitian ini menganalisis masalah peranan Tim Terpadu Penyelesaian Sengketa Kabupaten Ogan Komering Ilir dalam menyelesaikan sengketa lingkungan non-litigasi, yakni dengan proses mediasi antara perusahaan perkebunan kelapa sawit dengan warga Desa Sidomulyo. Penelitian ini memiliki tujuan agar penyelesaian sengketa yang dilakukan tim terpadu di kemudian hari, dapat memberikan solusi yang terbaik bagi para pihak serta untuk mendukung penyelenggaraan perkebunan kelapa sawit yang berkelanjutan. Metode penelitian ini dilakukan dengan pendekatan sosio-legal yang bermaksud melakukan penjelasan atas permasalahan yang diteliti dalam hubungannya dengan aspekaspek hukum dan sosial serta mencoba menjelajahi realitas empirik dalam penyelesaian sengketa. Dari hasil penelitian ini diketahui bahwa Tim Terpadu Penyelesaian Sengketa Kabupaten Ogan Komering Ilir telah melakukan tugasnya sesuai prosedur. Namun begitu ada beberapa hal yang memerlukan perbaikan dan penelitian ini memberikan solusi dalam pelaksanaannya. Pelaksanaan tugas tim terpadu yang memerlukan perbaikan, diantaranya adalah proses penyelesaian sengketa terlalu lama dan berlarut-larut. Kemudian, belum ada pengawasan terhadap kesepakatan penyelesaian sengketa yang dilakukan tim terpadu. Masalah selanjutnya adalah kekuatan mengikat dari suatu kesepakatan dalam sebuah penyelesaian sengketa non-litigasi. Selanjutnya tim terpadu menemui kendala yakni ketiadaan dokumen hak atas tanah yang sah milik warga desa. Terakhir, tim terpadu belum menggunakan mediasi dengan pendekatan kearifan lokal.
\end{abstract}

Kata kunci: berkelanjutan, kearifan lokal, masyarakat, perkebunan kelapa sawit, sengketa lingkungan.

\begin{abstract}
This research analyzes problem of the Integrated Team of Dispute Resolution of Ogan Komering Ilir District role in resolving non-litigation environmental dispute settlement, by a process of mediation between Oil Palm Plantation Company against Sidomulyo villagers. This research aims to resolve disputes that conducted by integrated team in the future, could provide the best solution for the parties and to support the implementation of sustainability palm oil plantations. This research method conducted with the socio-legal approach that intends to make the explanation of observed issues in relation with the legal and social aspects and try to explore empirical reality in dispute resolution. From the results of this research is known that Integrated Team of Dispute Resolution of Ogan Komering Ilir District has done its job in accordance with procedures. However there are several things that need of improvement and this research provides the solution implementation. Implementation of an integrated team tasks that need of improvement, including the dispute resolution process is too long and protracted. Then, there is no supervision of the dispute settlement agreement that conducted by integrated team. The next issue is the binding force of an agreement in a nonlitigation dispute resolution. Furthermore, an integrated team met some obstacles that lack land rights documents that rightfully belonged to the villagers. Finally, the integrated team not using local wisdom approach in the mediation process.
\end{abstract}

Keywords: sustainability, local wisdom, community, oil palm plantation, environmental dispute.

\section{PENDAHULUAN}

Undang-undang Perlindungan dan Pengelolaan Lingkungan Hidup menyebutkan bahwa sengketa lingkungan hidup adalah perselisihan antara dua pihak atau lebih yang timbul dari kegiatan yang berpotensi dan/atau telah berdampak pada lingkungan hidup. Penyebab sengketa lingkungan antara perusahaan perkebunan dengan masyarakat, menurut penelitian (Sembiring, 2009) yaitu adanya tuntutan pengembalian hak rakyat atas tanah perkebunan, yang didapatkan 
dengan cara merampas atau pemenuhan pembayaran nilai ganti rugi yang dianggap tidak sesuai yang diikuti dengan okupasi tanah oleh masyarakat termasuk penjarahan.

Pola perilaku manusia yang serakah dan hanya mementingkan diri sendiri, tanpa menghiraukan daya dukung sumberdaya alam dapat memicu suatu konflik atau sengketa (Armawi, 2013). Sengketa yang terjadi antara warga Desa Sidomulyo, Kecamatan Sungai Menang, Kabupaten Ogan Komering Ilir dengan perusahaan perkebunan kelapa sawit terjadi akibat adanya klaim sengketa lahan yang belum diganti rugi oleh pihak perusahaan. Hal tersebut memicu pendudukan lahan perusahaan dan demonstrasi beberapa warga di Kantor Bupati Ogan Komering Ilir.

Perusahaan dan masyarakat selayaknya dapat hidup berdampingan, saling menopang, simbiose mutualistik, sehingga pola hubungan yang tercipta dapat lebih harmonis, sinergis, dan tidak banyak konflik kepentingan antar stakeholder (Partini, 2013). Untuk menciptakan hubungan yang hrmonis dan menyelesaikan permasalahan tersebut, dilakukan upaya penyelesaian sengketa lingkungan melalui jalur non-litigasi, dengan cara mediasi oleh Tim Terpadu Penyelesaian Sengketa Kabupaten Ogan Komering Ilir. Mediasi mendasarkan suatu keputusan kepada kepentingan para pihak yang menghasikan kesepakatan perdamaian (Wynona dkk., 2013).

Permasalahan dalam penelitian ini adalah bagaimana tugas dan peranan tim terpadu penyelesaian sengketa dalam menyelesaikan sengketa lingkungan tersebut melalui jalur nonlitigasi yakni dengan proses mediasi, serta analisis proses penyelesaian sengketa lingkungan yang dilakukan oleh tim terpadu di Desa Sidomulyo. Penelitian ini memiliki tujuan agar penyelesaian sengketa yang dilakukan tim terpadu di kemudian hari membuahkan solusi yang terbaik bagi perusahaan perkebunan dan masyarakat untuk mewujudkan penyelenggaraan perkebunan kelapa sawit yang berkelanjutan.

\section{METODE PENELITIAN}

\section{Waktu dan Lokasi}

Penelitian dilakukan pada bulan Januari-April 2016 di di Kantor Sekretariat Tim Terpadu Penyelesaian Sengketa, Sekretariat Daerah Kabupaten Ogan Komering Ilir, Provinsi Sumatera Selatan dan lokasi sengketa di Desa Sidomulyo, Kecamatan Sungai Menang, Kabupaten Ogan Komering Ilir, Provinsi Sumatera Selatan

\section{Prosedur}

Prosedur penelitian ini dilakukan dengan pendekatan sosio-legal yang bermaksud melakukan penjelasan atas permasalahan yang diteliti dalam hubungannya dengan aspek-aspek hukum dan sosial serta mencoba menjelajahi realitas empirik dalam penyelesaian sengketa (Widowaty dan Fitriani, 2014). Studi sosio-legal adalah suatu pendekatan alternatif yang menguji studi doktrinal terhadap hukum, dimana ketika peneliti sosio-legal menggunakan teori sosial untuk tujuan analisis, mereka sering tidak sedang bertujuan untuk memberi perhatian pada sosiologi atau ilmu sosial yang lain, melainkan studi hukum khususnya yang berkaitan dengan lingkungan hidup (Banakar dan Travers, 2006).

\section{Pengumpulan dan Analisis Data}

Teknik pengumpulan data yang digunakan adalah dengan wawancara untuk mendapatkan sumber data primer. Wawancara adalah suatu cara untuk mendapatkan keterangan responden (Tim Terpadu Penyelesaian Sengketa Kabupaten Ogan Komering Ilir dan warga Desa Sidomulyo) melalui percakapan langsung dan berhadapan muka. Wawancara dilakukan dengan responden dengan mengajukan beberapa pertanyaan (panduan wawancara) yang sudah disiapkan. Pengambilan sampel dilakukan dengan metode non probability sampling secara purposive (Suprihati dkk., 2015), yaitu hanya pihak-pihak tim terpadu penyelesaian sengketa yang ikut dalam penyelesaian sengketa lingkungan dan juga warga Desa Sidomulyo yang dianggap tahu kronologis sengketa dan penyelesaiannya. Langkah terakhir yang digunakan adalah mengumpulkan data sekunder dengan mencari dokumentasi pelaksanaan penyelesaian sengketa lingkungan yang dilakukan Tim Terpadu Penyelesaian Sengketa Kabupaten Ogan Komering Ilir.

Dalam melakukan analisis data, digunakan analisis data deskriptif kualitatif, yaitu menggambarkan suatu keadaan atau status fenomena dengan kata-kata atau kalimat, kemudian dipisahkan menurut kategori untuk memperoleh kesimpulan. Kemudian, dalam mengolah data, upaya yang dilakukan antara lain (Arikunto, 2014): Analyzing, yaitu proses mencari dan menyusun secara sistematis data yang diperoleh dari hasil pengamatan (observasi), wawancara, catatan lapangan, dan studi dokumentasi yang dilakukan di Kantor Sekretariat Tim Terpadu Penyelesaian Sengketa dan lokasi sengketa di Desa Sidomulyo. Data tersebut dianalisis melalui teori-teori hukum, pendapat para ahli/ peneliti sebelumnya maupun peraturan perundang-undangan terkait untuk 
kemudian disimpulkan sehingga mudah difahami oleh diri sendiri dan orang lain. Langkah terakhir yakni Concluding, dengan mengambil kesimpulan yang ditarik berdasarkan data yang telah dikumpulkan dan merupakan jawaban yang benarbenar dicari.

\section{HASIL DAN PEMBAHASAN}

\section{Tugas dan Peran Tim Terpadu Penyelesaian Sengketa}

Peraturan perundang-undangan bidang perkebunan mengisyaratkan bahwa para pelaku usaha perkebunan wajib menyelesaikan sengketa lahan yang ada di dalam areanya. Hal tersebut adalah suatu syarat apabila perusahaan perkebunan akan mengajukan sistem sertifikasi kelapa sawit berkelanjutan atau ISPO. Salah satu indikator ISPO tersebut adalah perusahaan perkebunan kelapa sawit wajib menyelesaikan sengketa dengan melibatkan instansi yang terkait dalam hal ini tim terpadu penyelesaian sengketa (Anonim, 2015).

Penyelesaian sengketa yang dilakukan melalui jalur non-pengadilan atau non-litigasi didasarkan pada anggapan bahwa penyelesaian sengketa lingkungan yang diajukan ke pengadilan atau litigasi, hasilnya sangat mengecewakan masyarakat yang mendapat imbas dari adanya sengketa lingkungan (Absori dkk, 2008). Selain itu tujuan diaturnya penyelesaian sengketa di luar pengadilan adalah untuk melindungi hak keperdataan para pihak yang bersengketa dengan cara cepat dan efisien (Artadi, 2007). Hal ini mengingat penyelesaian sengketa melalui jalur litigasi cenderung membutuhkan waktu lama dan biaya yang relatif tidak sedikit. Hal ini disebabkan proses penyelesaian sengketa lambat, biaya beracara di pengadilan mahal, pengadilan di anggap kurang responsif dalam penyelesaian perkara, sehingga putusan sering tidak mampu menyelesaikan masalah dan penumpukan perkara (Sawitri dan Bintoro, 2010).

Berdasarkan wawancara dengan Kepala Desa Sidomulyo, kronologis sengketa yang terjadi antara perusahaan perkebunan dengan warga bermula ketika pada tanggal 10 Desember 2013, sekitar pukul 09.00 WIB, sekelompok warga yang diketuai oleh Ida Bagus Alit menduduki lahan kebun perusahaan dengan mendirikan tenda serta bermukim di kebun milik perusahaan. Kelompok masyarakat tersebut juga melarang aktivitas pemanenan dan perawatan kebun dengan cara memblokir jalan poros dan melakukan pengancaman apabila dilakukan perawatan dan pemanenan. Akibat pendudukan tersebut, aktivitas perusahaan terhenti.
Kemudian, pada tanggal 29 Januari 2014, kelompok Ida Bagus Alit tersebut menyatakan tuntutannya kembali dengan cara melakukan demonstrasi ke kantor Pemerintah Kabupaten Ogan Komering Ilir dengan membawa fotocopy surat kepemilikan tanah berupa surat pengakuan hak sebanyak 735 surat. Pada saat itu demonstran ditemui oleh Bupati Ogan Komering Ilir dan menyatakan akan berupaya memfasilitasi penyelesaian sengketa dan akan meneliti permasalahannya. Untuk menyelesaikan sengketa lingkungan ini maka tugas ini dilimpahkan kepada Tim Terpadu Penyelesaian Sengketa Kabupaten Ogan Komering Ilir.

Mekanisme penyelesaian sengketa lingkungan yang dilakukan untuk kasus sengketa perkebunan di Desa Sidomulyo dilakukan dengan cara mediasi sebagai salah satu cara dalam penyelesaian sengketa lingkungan non-litigasi. Penyelesaian sengketa lingkungan melalui mediasi lebih menghemat waktu dan biaya serta bisa lebih dipercaya oleh masyarakat dibandingkan cara litigasi atau jalur pengadilan (Levy, 2013). Tim terpadu ini dibentuk berdasarkan Surat Keputusan Bupati Ogan Komering Ilir Nomor: 542/KEP/II/2012 Tentang Pembentukan Tim Terpadu Penyelesaian Sengketa Kabupaten Ogan Komering Ilir. Berdasarkan Surat Keputusan tersebut, tugas Tim Terpadu Penyelesaian Sengketa Kabupaten Ogan Komering Ilir secara garis besar adalah mendata dan menginventarisir, mengidentifikasi, melakukan penelitian mendalam secara administrasi dan perkembangannya di lapangan, menetapkan langkah-langkah percepatan penyelesaian sengketa, menuntaskan sengketa dan membuat laporan tertulis terkait hasil penyelesaian sengketa lingkungan dan lahan, perkebunan, tata batas desa, kelurahan, dan kecamatan yang ada dalam lingkup Kabupaten Ogan Komering Ilir.

Susunan Tim Terpadu Penyelesaian Sengketa ini berasal dari berbagai Satuan Kerja Perangkat Daerah (SKPD) di lingkungan Kabupaten Ogan Komering Ilir, dengan Wakil Bupati Ogan Komering Ilir sebagai ketua serta Asisten I Sekretariat Daerah Kabupaten Ogan Komering Ilir sebagai pelaksana harian. Sementara itu, sebagai panduan tim terpadu dalam menangai penyelesaian sengketa dimana prosedur ini merupakan sarana untuk menyelesaikan sengketa lingkungan dan memperkecil masalah sosial, prosedur tersebut dibuat melalui Peraturan Bupati Ogan Komering Ilir Nomor: 643 Tahun 2014 Tentang Prosedur Pengaduan dan Pedoman Penanganan Penyelesaian Sengketa di Kabupaten Ogan Komering Ilir. Dari Peraturan Bupati tersebut diketahui, ruang lingkup penyelesaian sengketa yang ditindaklanjuti Tim 
Terpadu antara lain: Pemerintah Kabupaten dengan masyarakat, Pemerintah Kabupaten dengan perusahaan, perusahaan dengan perusahaan, masyarakat dengan perusahaan, kelompok masyarakat dengan kelompok masyarakat lainnya yang berdampak luas khususnya pada lingkungan hidup. Dari ketentuan tersebut dapat diketahui bahwa sengketa yang terjadi antara perusahaan dengan masyarakat merupakan salah satu kewenangan yang dimiliki oleh Tim Terpadu Penyelesaian Sengketa.

Penanganan penyelesaian sengketa oleh tim terpadu dilakukan dengan cara mediasi kedua belah pihak untuk mencapai kesepakatan atau penyelesaian sengketa di luar pengadilan atau nonlitigasi. Penanganan yang dilakukan oleh tim terpadu ini dapat ditindaklanjuti apabila sengketa yang terjadi telah dilakukan mediasi di tingkat desa dan atau kecamatan namun tidak mencapai kata sepakat.

Tugas pokok tim terpadu dalam melaksanakan penyelesaian sengketa dilakukan melalui upaya mediasi atau upaya penyelesaian sengketa di luar pengadilan/ non-litigasi berdasarkan kajian teknis dan yuridis serta ketentuan peraturan yang berlaku. Apabila para pihak telah menyerahkan penyelesaian sengketa kepada tim terpadu, gugatan melalui jalur pengadilan hanya dapat ditempuh apabila upaya mediasi dinyatakan tidak berhasil. Jika salah satu pihak berkeberatan maka para pihak dapat menempuh jalur penyelesaian sengketa melalui pengadilan. Tim terpadu tidak akan menindaklanjuti penyelesaian sengketa apabila salah satu pihak telah mengajukannya ke pengadilan terlebih dahulu. Untuk itu apabila sengketa telah memiliki kekuatan hukum tetap/ inkracht van gewijsde maka tim terpadu tidak akan melakukan mediasi.

Penyelesaian sengketa yang difasilitasi tim terpadu diselenggarakan untuk mencapai kesepakatan mengenai bentuk besaran tuntutan dan atau mengenai bentuk tindakan tertentu berdasarkan kajian teknis dan atau berdasarkan ketentuan lainnya guna menjamin tidak terulangnya tuntutan di objek yang sama oleh pihak lain. Rumusan hasil kajian teknis dan atau hasil kajian tim lainnya yang berkenaan dengan penyelesaian yang telah ditindaklanjuti, dituangkan dalam berita acara atau bentuk hasil kesimpulan akhir tim. Rumusan tersebut, apabila diperlukan para pihak dapat dijadikan acuan dalam penyelesaian lanjutan.

Penyelesaian sengketa yang telah selesai ditindaklanjuti oleh tim terpadu yang dituangkan dalam laporan hasil kesimpulan akhir tim untuk dilaporkan kepada Bupati untuk memohon petunjuk atau arahan. Setelah mendapat petunjuk atau arahan dari Bupati, tim terpadu mengeluarkan rekomendasi yang disampaikan kepada para pihak dengan tembusan disesuaikan dengan pokok permasalahan.

Proses Penyelesaian sengketa yang terjadi di Desa Sidomulyo dilakukan oleh Tim Terpadu Penyelesaian Sengketa Kabupaten Ogan Komering Ilir, dengan mengadakan penelitian lapangan ke lokasi perusahaan perkebunan kelapa sawit yang mana sebagian lahannya di klaim oleh kelompok masyarakat yang dipimpin oleh Ida Bagus Alit. Tujuan peninjauan lapangan oleh tim terpadu adalah untuk menggetahui letak/posisi lahan yang dituntut atau belum di bayar ganti ruginya.

Berdasarkan hasil wawancara dengan pelaksana tugas tim terpadu penyelesaian sengketa, hasil peninjauan lapangan yang dilakukan diperoleh data sebagai berikut:

a. Lahan yang dituntut oleh kelompok Ida Bagus Alit terletak di dalam areal HGU milik perusahaan perkebunan kelapa sawit.

b. Pada saat dilakukan observasi oleh tim terpadu, kelompok masyarakat yang dipimpin oleh Ida Bagus Alit kebingungan mencari letak/posisi lahan yang dituntut.

c. Setelah dilakukan peninjauan lapangan tersebut, kelompok Ida Bagus Alit yang menduduki lahan sejak tanggal 10 Desember 2013, kemudian meninggalkan lahan yang diduduki pada tanggal 24 Desember 2013.

Kemudian tim terpadu juga melakukan penelusuran data yang dimiliki oleh perusahaan perkebunan dimana hasilnya sebagai berikut:

a. Lahan yang telah memiliki Hak Guna Usaha telah dilakukan ganti rugi sesuai prosedur

b. Kelompok masyarakat yang telah menerima ganti rugi tersebut bersedia bertanggung jawab baik secara pidana maupun perdata terhadap keabsahan kepemilikan lahan mereka.

Dari hasil peninjauan lapangan tersebut, maka kesimpulan dari Tim Terpadu Penyelesaian Sengketa Kabupaten Ogan Komering Ilir, atas kasus sengketa antara perkebunan kelapa sawit dengan warga Desa Sidomulyo adalah sebagai berikut:

a. Pada awalnya kelompok warga yang dipimpin oleh Ida Bagus Alit menuntut 450 surat yang ada dalam areal HGU perusahaan, namun pada tanggal 29 Januari 2014 kelompok ini menyatakan tuntutannya terhadap perusahaan melalui demonstrasi ke Kantor Bupati Ogan Komering Ilir dengan membwa fotocopy Surat Pengakuan Hak sebanyak 735 surat atau bertambah dari tuntutan sebelumnya.

b. Surat tanah yang diajukan Ida Bagus Alit tersebut, diduga diragukan keabsahannya. 
c. Perusahaan berjanji untuk menyelesaikan dan mengganti rugi lahan milik warga yang belum diganti rugi, dengan catatan masyarakat dapat mengumpulkan bukti-bukti terkait dengan dokumen lahan tersebut.

d. Bahwa HGU yang dimiliki perusahaan perkebunan, telah didapatkan sesuai ketentuan peraturan perundang-undangan yang berlaku, dan pada lahan yang dituntut oleh kelompok Ida Bagus Alit serta masyarakat lainnya telah dilaksanakan ganti kerugian oleh perusahaan kepada sejumlah kelompok masyarakat.

Dari hasil rekomendasi tim terpadu dapat disimpulkan bahwa perusahaan perkebunan telah melakukan ganti rugi yang secara prosedural. Berdasarkan hasil penelitian tim terpadu ini, ditemukan permasalahan di Desa Sidomulyo yaitu lahan-lahan masyarakat tersebut banyak yang tidak memiliki Sertifikat Hak Milik. Berdasarkan hasil wawancara dengan warga Desa Sidomulyo, mereka tetap mengklaim bahwa tanah yang mereka miliki berasal dari turun temurun, namun mereka tidak dapat membuktikan letak dan posisi, peta tanah serta tidak dilakukannya pemanfaatan tanah dengan baik atau tanahnya dibiarkan terbengkalai.

\section{Analisis Proses Penyelesaian Sengketa Tim Terpadu Penyelesaian Sengketa}

Berdasarkan hasil wawancara dengan Asisten I Sekretaris Daerah Ogan Komering Ilir, sebagai Pelaksana Harian tugas Tim Terpadu Penyelesaian Sengketa Kabupaten Ogan Komering Ilir, sengketa lingkungan yang terjadi antara perusahaan perkebunan dengan warga Desa Sidomulyo tersebut sudah selesai dan menghasilkan suatu rekomendasi bagi kedua belah pihak. Namun begitu dalam prosesnya masih terdapat beberapa kendala yang perlu diperbaiki. Dari data-data yang dianalisis, didapatkan beberapa evaluasi yang perlu diperbaiki oleh tim terpadu penyelesaian sengketa Kabupaten Ogan Komering Ilir.

Pertama, proses penyelesaian sengketa terlalu lama dan berlarut-larut karena tim terpadu sering tidak bertemu secara langsung dengan pimpinan perusahaan yang dapat bertanggung jawab secara korporasi. Pada saat dilakukan mediasi di Desa Sidomulyo, pihak perusahaan sering mengutus staf yang tidak berwenang mengambil keputusan atau tidak bisa bertanggung jawab secara hukum dalam korporasi. Dalam hal ini, tim terpadu seyogyanya mewajibkan pihak pimpinan perusahaan yang bisa memberikan keputusan agar hadir dari awal hingga selesainya proses penyelesaian sengketa. Jika pimpinan perusahaan sejak awal mengikuti proses penyelesaian sengketa, tentunya proses ini tidak akan berlarut-larut. Menurut pelaksana harian tugas
Tim Terpadu Penyelesaian Sengketa Kabupaten Ogan Komering Ilir, pelaksanaan penyelesaian sengketa tersebut memakan waktu hingga 2 (dua) tahun, yakni sejak tahun 2013 hingga tahun 2015.

Kedua, belum adanya pengawasan terhadap kesepakatan penyelesaian sengketa di Desa Sidomulyo. Dari hasil wawancara diketahui bahwa kesepakatan dalam penyelesaian sengketa lingkungan atas lahan di Desa Sidomulyo ini belum ada pengawasan dari Tim Terpadu Penyelesaian Sengketa. Obidzinski berpendapat bahwa lembaga pemerintah (dalam hal ini Tim Terpadu Penyelesaian Sengketa), harus memantau hasil mediasi antara masyarakat dengan perusahaan dan memastikan tidak ada sengketa lahan yang berikutnya. Jika hal ini tidak dilakukan, maka dikhawatirkan akan menimbulkan masalah di kemudian hari apabila perusahaan perkebunan maupun masyarakat (warga Desa Sidomulyo) mengingkari kesepakatan yang telah dibuat oleh para pihak melalui fasilitasi dari mediator (Tim Terpadu Penyelesaian Sengketa Kabupaten Ogan Komering Ilir) (Obidzinski dkk, 2012). Untuk itu, kesepakatan yang dibuat para pihak perlu pengawasan dalam pelaksanaannya.

Ketiga, masalah kekuatan mengikat suatu kesepakatan dilaksanakan dalam sebuah penyelesaian sengketa non-litigasi merupakan masalah yang krusial. Menurut (Herliana, 2011), kelemahan yang paling utama dalam setiap putusan penyelesaian sengketa non-litigasi adalah kesepakatan yang telah dicapai tidak mempunyai kekuatan hukum seperti layaknya putusan pengadilan. Pada prakteknya banyak kesepakatan dalam penyelesaian sengketa non-litigasi yang tidak dapat dilaksanakan karena satu atau kedua belah pihaknya tidak mau melaksanakan kesepakatan secara sukarela. Hal ini menunjukkan hasil mediasi ini tidak final dan mengikat.

Untuk itu, kesepakatan mediasi antara para pihak tersebut harus didaftarkan di pengadilan untuk mendapat kekuatan hukum yang mengikat. Dengan demikian, penyelesaian sengketa nonlitigasi melalui mediasi dari Tim Terpadu Penyelesaian Sengketa Kabupaten Ogan Komering Ilir, tetap tidak terlepas dari peran dan tanggungjawab lembaga pengadilan, yang dalam hal ini adalah Pengadilan Negeri untuk dapat kekuatan mengikat (Talib, 2013).

Keempat, tim terpadu menemui kendala yakni ketiadaan dokumen hak atas tanah yang sah milik warga Desa Sidomulyo yang bersengketa dengan perusahaan. Kendala ketiadaan dokumen hak atas tanah yang sah ini banyak ditemukan di Desa Sidomulyo, dimana kepemilikan tanah mayoritas adalah pewarisan turun temurun dan tanah tersebut 
tidak dikelola dengan baik. Untuk itu sangat sulit pembuktiaannya apakah tanah yang di klaim warga tersebut adalah milik mereka atau bukan. Oleh karena itu, tim terpadu seyogyanya memberikan rekomendasi kepada Kepala Desa Sidomulyo agar pro-aktif mendorong warganya untuk melakukan pendaftaran tanah ke Kantor Pertanahan yang ada di Kabupaten Ogan komering Ilir. Hal ini supaya warga mendapatkan Sertifikat Hak Milik sehingga dapat menjamin kepastian hukum atas lahan yang mereka miliki (Dewi, 2010).

Kelima, Tim Terpadu Penyelesaian Sengketa Kabupaten Ogan Komering Ilir belum menggunakan mediasi dengan pendekatan kearifan lokal dalam menyelesaikan sengketa lingkungan yang terjadi di Desa Sidomulyo. Penyelesaian sengketa lingkungan melalui mekanisme kearifan lokal lebih efektif dan prosesnya tidak terlalu lama serta hubungan kekerabatan yang ada lebih dieratkan (Hendra, 2013). Proses penyelesaian sengketa yang dilakukan oleh tim terpadu dapat dikatakan sebagai mediasi konvensional, yakni secara garis besar melakukan penelitian atas kelengkapan berkas, pemeriksaan saksi-saksi, peninjauan lapangan, penelaahan data yuridis dengan data fisik dan administrasi. Penyelesaian sengketa non-litigasi menggunakan proses mediasi konvensional tersebut mungkin selesai di permukaan, namun tidak sampai pada akar-akar permasalahan di dalam berlakunya hukum pada warga Desa Sidomulyo.

Salah satu pola kearifan lokal dalam bertani dan berkebun yang ada di Desa Sidomulyo, seperti kebanyakan yang juga dikenal di masyarakat di Kabupaten Ogan Komering Ilir dikenal perjanjian bagi hasil dengan istilah paroan (bagi duo atau bagi due $=$ bagi dua), yang artinya adanya bagi hasil pertanian dan perkebunan antara pemilik dan penggarap lahan. Jadi dalam pembagian hasil perkebunan dan pertanian tersebut, ketentuanketentuan adat setempat merupakan unsur yang perlu diperhatikan untuk mencapai keadilan dan kedamaian masyarakat. Berdasarkan hasil wawancara dengan masyarakat di Desa Sidomulyo, walaupun saat ini pembagiannya tidak dibagi dua (biasanya $60 \%$ untuk pemilik lahan dan $40 \%$ untuk penggarap lahan), namun menurut mereka imbangan yang mereka terima cukup adil, dan baik pemilik maupun pengarap lahan tidak merasa dirugikan dengan pembagian tersebut. Dengan demikian dapat dikatakan bahwa bagi hasil di Desa Sidomulyo dapat mensejahterakan masyarakat setempat.

Pola kearifan lokal tersebut sebetulnya dapat dimasukkan dalam rekomendasi bagi hasil perkebunan melalui pembangunan perkebunan plasma untuk masyarakat di areal Hak Guna Usaha perkebunan milik perusahaan di wilayah Desa Sidomulyo. Menurut Sumardjo, salah satu solusi untuk menyelesaikan sengketa adalah pemberian lahan kebun plasma kepada masyarakat khususnya pemilik lahan yang digunakan untuk perkebunan oleh pihak perusahaan (Sumardjo dkk, 2014). Dengan hal tersebut, masyarakat diharapkan dapat ikut merasakan hasil dan manfaat adanya perusahaaan perkebunan di desa mereka.

Untuk itu mekanisme penyelesaian sengketa lingkungan non-litigasi melalui mediasi yang dilakukan oleh Tim Terpadu Penyelesaian Sengketa Kabupaten Ogan Komering Ilir, perlu memasukkan nilai-nilai kearifan lokal yang dirasakan lebih bisa diterima sebagai benefit-benefit solution oleh masyarakat. Penaatan (genuine recognition) terhadap mekanisme-mekanisme pengaturan lokal (innerorder mechanism) yang secara nyata tumbuh dan berkembang dalam masyarakat harus dilakukan dihargai (Nurjaya, 2011). Implikasinya, nilai-nilai, prinsip-prinsip hukum, institusi, dan tradisi folk law seyogyanya dapat diakomodasi dalam mekanisme penyelesaian sengketa lingkungan non-litigasi ini. Model mediasi dengan pendekatan kearifan lokal ini perlu dikembangkan untuk membina hubungan baik dengan masyarakat dengan cara merespons dan mengakomodasi nilai, asas, norma, institusi, dan tradisi yang tumbuh dan berkembang secara empirik dalam kehidupan masyarakat.

Upaya penyelesaian sengketa non-litigasi melalui mediasi yang dilakukan secara kelembagaan melalui kolaborasi kelembagaan (Tim Terpadu Penyelesaian Sengketa) perlu dilakukan secara berkelanjutan agar potensi sengketa tidak semakin meluas (Hafrida dkk, 2014). Namun begitu pelaksanaan penyelesaian sengketa non-litigasi melalui mediasi oleh tim terpadu ini perlu terus di evaluasi agar pelaksanaannya semakin baik dan hasil mediasi tersebut dapat diterima oleh para pihak yang bersengketa. Hal ini juga untuk mendukung investasi perkebunan kelapa sawit yang berkelanjutan, aman, dan berwawasan lingkungan di wilayah Kabupaten Ogan Komering Ilir.

\section{KESIMPULAN}

Tim Terpadu Penyelesaian Sengketa Kabupaten Ogan Komering Ilir telah berperan sebagai fasilitator yang netral dan independen, dalam rangka melakukan penyelesaian sengketa lingkungan non-litigasi melalui mediasi antara perusahaan perkebunan kelapa sawit dengan warga Desa Sidomulyo, Kecamatan Sungai Menang, Kabupaten Ogan Komering Ilir. Namun begitu, berdasarkan analisis penelitian ini ada beberapa masalah dalam proses mediasi Tim Terpadu 
Penyelesaian Sengketa Kabupaten Ogan Komering Ilir yang masih memerlukan perbaikan.

Solusi terhadap perbaikan-perbaikan dari beberapa masalah yang telah disebutkan dalam analisis penelitian ini, diharapkan dapat dijadikan masukan bagi proses penyelesaian sengketa di kemudian hari agar hasilnya lebih baik dan menghasilkan benefit-benefit solution bagi perusahaan maupun masyarakat, serta untuk menyelesaikan permasalahan sosial dan lingkungan yang masih dalam ruang lingkup tugas dari Tim Terpadu Penyelesaian Sengketa Kabupaten Ogan Komering Ilir. Diharapkan masukan-masukan dalam analisis penelitian ini dapat dijadikan dasar dalam perubahan Peraturan Bupati Ogan Komering Ilir Nomor 643 Tahun 2014 Tentang Prosedur Pengaduan dan Pedoman Penanganan Penyelesaian Sengketa di Kabupaten Ogan Komering Ilir. Hal tersebut dikarenakan perubahan Peraturan Bupati tersebut merupakan payung hukum Tim Terpadu Penyelesaian Sengketa Kabupaten Ogan Komering Ilir dalam menyelesaikan sengketa lingkungan di wilayah Kabupaten Ogan Komering Ilir.

\section{DAFTAR PUSTAKA}

Absori, Dimyati, K., dan Wardiono, K., 2008. Model Penyelesaian Sengketa Lingkungan Melalui Lembaga Alternatif. Jurnal Mimbar Hukum, 20(2):193 - 410.

Anonim, 2015. Peraturan Menteri Pertanian Nomor 11/Permentan/OT.140/3/2015 Tentang Sistem Sertifikasi Kelapa Sawit Berkelanjutan Indonesia (Indonesian Sustainable Palm Oil Certification System /ISPO), Jakarta.

Arikunto, S., 2014. Prosedur Penelitian Suatu Pendekatan Praktik. PT. Rineka Cipta, Jakarta.

Armawi, A., 2013. Kajian Filosofis Terhadap Pemikiran Human-Ekologi Dalam Pemanfaatan Sumber Daya Alam. Jurnal Manusia dan Lingkungan, 20(1):57-67.

Artadi, I., 2007. Dekonstruksi Pemahaman Penyelesaian Perkara Pidana Melalui Prosedur Perdamaian Menuju Proses Peradilan Pidana Rekonsiliatif. Jurnal Hukum Pro Justitia, 25(1):30-41.

Banakar, R., dan Travers, M., 2006. Theory and Method in Socio-Legal Research. Hart Publishing, Oxford.

Dewi, I.G.S., 2010. Peran Camat Selaku Pejabat Pembuat Akta Tanah (PPAT) dalam Jual Beli Tanah. Jurnal Pandecta, 5(2):120-131.

Hafrid, Haryadi, Yahya, T., Kusniati, R., dan Idris, I., 2014. Penyuluhan Hukum Resolusi Konflik Sumber Daya Alam di Kabupaten Batanghari. Jurnal Pengabdian Masyarakat, 29(4):59-72.
Hendra, 2013. Totua Ngata dan Konflik (Studi atas Posisi Totua Ngata sebagai Lembaga Adat di Kecamatan Marawola). Jurnal Antropologi Indonesia, 34(1):15-28.

Herliana, 2011. Peranan Koordinasi Penyelesaian Permasalahan Lingkungan Hidup Dalam Menyelesaikan Sengketa Lingkungan di DIY. Jurnal Mimbar Hukum, 23 (1): 98-114.

Levy, L.J., 2013. Why Mediation Succeeds In Environmental Cleanup and Mass Tort Cases. Westlaw Journal Environmental, 33(25):1-5.

Nurjaya, I.N., 2011. Memahami Kedudukan dan Kapasitas Hukum Adat Dalam Politik Pembangunan Hukum Nasional. Jurnal Perspektif, 16(4): 36-243.

Obidzinski, K., Andriani, R., Komarudin, H., dan Andrianto, A., 2012. Environmental and Social Impacts of Oil Palm Plantations and Their Implications for Biofuel Production. Journal Ecology and Society, 17(1):25-44.

Partini, 2013. CSR dan Pemberdayaan Masyarakat (Studi Imlementasi CSR-PTBA di Muara Enim, Sumatera Selatan). Jurnal Manusia dan Lingkungan, 20(1):84-99.

Sawitri, H.W. dan Bintoro, R.W., 2010. Sengketa Lingkungan dan Penyelesaiannya. Jurnal Dinamika Hukum, 10 (2):163-174.

Sembiring, J., 2009. Konflik Tanah Perkebunan di Indonesia. Jurnal Hukum, 3(16):337-353.

Sumardjo, Riyanto, S., Saleh, A., Dahri, dan Firmansyah, A., 2014. Tipologi Konflik Berbasis Sumber Daya Pangan di Wilayah Perkebunan Sawit, Jurnal Ilmu Pertanian Indonesia, 19(3):189-196.

Suprihati, Yuliawati, Soetjipto, H., dan Wahyono, T., 2015. Persepsi Petani dan Adaptasi Budidaya Tembakau-Sayuran Atas Fenomena Perubahan Iklim di Desa Tlogolele, Kecamatan Selo, Kabupaten Boyolali. Jurnal Manusia dan Lingkungan, 22(3):326-332.

Talib, I., 2013. Bentuk Putusan Penyelesaian Sengketa Berdasarkan Mediasi. Jurnal Lex et Societatis, 1(1):19-30.

Widowaty, Y., dan Fitriyanti, F., 2014. Membangun Model Perlindungan Hukum Terhadap Masyarakat Sebagai Korban Pencemaran dan/Atau Perusakan Lingkungan Oleh Korporasi dengan Prinsip Restorative Justice. Jurnal Media Hukum, 21(1):1-19.

Wynona, A., Sina L., dan Erawaty, R., 2013. Penyelesaian Sengketa Lingkungan Hidup Melalui Mediasi Antara Masyarakat dengan Perusahaan di Sekitar Kelurahan Bukuan Kecamatan Palaran Kota Samarinda. Jurnal Beraja Niti, 2(8):1-16. 